\title{
Hideko Takamine
}

\author{
By Ron Holloway \\ Spring 1994 Issue of KINEMA
}

AT SEVENTY, she's Japan's greatest living actress, often compared to Mary Pickford, but more like a Katherine Hepburn for the range of her talent and commanding presence of the screen -- Hideko Takamine.

Despite being recognized as a screen immortal in Japan, only a handful of her more than three hundred film appearances are known in the United States, due to the tragic destruction of the Japanese film archives during the war. Thus she's known in the West mostly by her postwar films, made during that last great period of Japanese cinema of the 1950s and early 1960s, after which television was to replace moviegoing as the population's favourite form of entertainment.

Rather late in her career, Takamine did venture into television, but was never satisfied with the results. Finally, in 1979, deciding that the new medium was not for her, she gracefully took leave of the screen to enjoy for the first time in five decades the pleasures of a private life.

When at the last Tokyo Film Festival I asked to interview her, Japanese critics told me that such was impossible: "She just doesn't give interviews." But a mutual friend, film historian Akira Shimizu, intervened on my behalf for a casual meeting, which was arranged one afternoon at the International House.

To put the record straight, Hideko Takamine has been interviewed at length by American journalist Phyllis Birnbaum for a "Profile" published in New Yorker in November of 1990. Moreover, her key postwar films -made together with Mikio Naruse, one of her two favourite directors -- were programmed by American film historian Audie E. Bock for a Naruse retrospective at the 1983 Locarno film festival. And Akira Shimizu has recently written an authoritative monograph on her life and career.

Born in Hokkaido, Hideko Takamine entered silent movies as a child star at the Shochiku Tokyo Studios when she was five years old. Her first film, Mother (1929), was such a box office hit, due primarily to her performance, that a career was established on the spot. Immediately thereafter, she enjoyed the same popularity on Tokyo screens as Shirley Temple did -- indeed, they were often double-billed on the marquee.

From everybody's "little girl," she became "the girl next door," and then a popular teenaged pin-up star whose photo was carried by young Japanese soldiers into the front lines of World War Two next to those of sisters and girlfriends.

In the files of great Japanese actresses, Hideko Takamine -- particularly in those films made together with directors Mikio Naruse and Keisuke Kinoshita -- takes her place next to Kinuyo Tanaka under Kenji Mizoguchi's direction and Setsuko Hara in Yasujiro Ozu's films. And it was largely due to her performances in Kinoshita's Twenty-four Eyes (1954) and Naruse's Floating Clouds (1955) that these films were chosen "Best Ones" by the authoritative Kinema Jumbo magazine.

As an actress who matured with the demands of ever-changing roles, she soon mastered all genres and character types. Indeed, her professionalism at the age of 17 played a hand even in the development of Akira Kurosawa's career, who as Kajiro Yamamoto's assistant on Horses (1941) filmed her outdoor scenes in the Tohoku mountain district. It was she who later called his attention to a talented young actor at the Toho Studios: Toshiro Mifune.

The daughter of poor parents and one guided by a stern foster-mother who herself never attended school, Hideko Takamine for all practical purposes had to educate herself between acting chores. Later, at the age of 27 , after she had taken a long-delayed stand for her own independence by remaining six months abroad in Paris, she returned home to put her career squarely on the line by breaking with the studios to freelance as an actress. The gamble paid off: she was more in demand than ever before.

Her trip to Europe was exceptional in every respect, for Japanese citizens in 1950 still had to receive official permission from the American Occupation Forces to leave the country. An invitation to attend the Venice Film Festival got her as far as Paris, where she simply got off the plane and esconsed herself in a pension, 
aided in her escapade by a kindly professor of Oriental Literature at the Sorbonne. She later wrote an account of her experiences of being Alone in Paris, the first of several books she's written.

Back in Japan, Takamine became not only a top screen personality, but an adept business woman as well. Her unbending will was to self-determine her fortune and future throughout the 1950s, during which time she alternately starred in a series of films directed by stylists Kinoshita and Naruse. More often than not, the films were rated among the best of the season in addition to being commercial successes.

For Kinoshita, she usually played spirited, independent females who embodied a new generation of Japanese womanhood breaking with the restrictive customs of the past. The trend began with the comedy Carmen Comes Home (1951) -- presenting her shockingly as a liberated stripteaser baring her legs on a trip back to her rural home -- and culminated in Twenty-four Eyes (1954), in which her performance as a schoolteacher underscored the pride and integrity of a people ready to take their place in the world. Voted "Best Film," Kinoshita's Twenty-four Eyes was acclaimed by French critic Georges Sadoul as a sure winner at the Venice festival, had it been entered in the competition.

For Naruse, she embodied an entirely different woman: one from the underprivileged classes and usually a tragic figure who endures despite the whims of fate. Her performance in Floating Clouds (1955) -- following on the heels of Twenty-four Eyes of the year before -- was again voted Best Film, thus confirming her status in the Japanese press as a screen legend, albeit at the tender age of 30. More classic Naruse-Takamine films were to follow: Flowing (1956), Untamed (1957), When a Woman Ascends the Stairs (1960), and Yearning (1964).

Each of these films gives testimony to a unique manner of working together as director and actress. Takamine recounted at the International House how Naruse would go through the script page by page with her, crossing out patches of dialogue that she could render without words, or by a glance, or by a gesture, or simply by her "presence." Later, during the actual shooting, they hardly had to speak to each other.

Now retired, and married for the past 37 years to director-screenwriter Zenzo Matsuyama, Hideko Takamine spends half of each year at her home in Tokyo. For the other half, she lives anonymously at the family's second residence in Hawaii.

\section{Author Information}

Ron HOLLOWAY (1933-2009) was an American critic, film historian, filmmaker and correspondent who adopted Europe as his home in the early fifties and spent much of his life in Berlin. He was an expert on the study of German cinema and against all odds produced, with his wife Dorothea, the journal German Film, keeping us up-to-date with the work of directors, producers and writers and the showing of German films around the world.

In 2007, Ron Holloway and his wife were awarded the Berlinale Camera Award. Ron also received the Bundesverdienstkreuz (German Cross of Merit), Polish Rings, Cannes Gold Medaille, the American Cinema Foundation Award, the Diploma for Support of Russian Cinema and an honorary award from the German Film Critics' Association.

Ron was also a valued contributor to Kinema for the past fifteen years. 